\title{
KAJIAN \\ PRODUKTIVITAS TUKANG BATU TERHADAP BEBAN KERJA DAN WAKTU ISTIRAHAT PADA PEKERJAAN KONSTRUKSI BANGUNAN
}

\author{
Elvira Handayani dan Annisaa Dwiretnani \\ (Dosen Teknik Sipil Unbari)
}

\begin{abstract}
Abstrak
Produktivitas menjadi isu dominan dalam industri jasa konstruksi. Dengan produktivitas yang tinggi, akan dicapai efisiensi pemakaian sumber daya serta penghematan biaya, sehingga perusahaan konstruksi akan meraih profit yang memadai serta memiliki daya saing (competitiveness) yang tinggi. Produktivitas tenaga kerja pun dapat dipengaruhi oleh energi yang ia konsumsi dan pengaturan jadwal istirahat yang rutin. Istirahat diperlukan untuk memulihkan kesegaran fisik maupun mental tenaga kerja. Hal ini didasarkan atas penelitian Murrel (1965) dimana pengaturan waktu kerja yang diselingi dengan beberapa kali waktu istirahat akan menaikkan produktivitas pekerja. Berdasarkan penelitian yang dilakukan terhadap 37 tukang pasangan bata, maka dapat diambil kesimpulan penelitian sebagai berikut: 1) Pada penelitian ini faktor umur, pendidikan, maupun pengalaman tidak terlalu berpengaruh pada produktivitas yang dihasilkan. Variasi profil tukang di beberapa proyek penelitian tidak membuktikan bahwa tingkat produksi yang di hasilkan berbeda-beda; 2) Waktu istirahat yang diperoleh tukang pada penelitian ini dalam sehari sangat bervariatif. Pada penelitian ini waktu istirahat curian maupun faktor manajemen yang diperoleh tukang antara 1 menit hingga 6 menit setiap pengamatan (30 menit). Maka dapat disimpulkan bahwa waktu istirahat yang diperoleh dalam sehari cukup banyak; 3) Waktu istirahat yang di peroleh di tengah bekerja tukang sangat mempengaruhi tingkat produktivitas tukang. Tukang belum mengalami kelelahan dan belum membutuhkan pengaturan jadwal istirahat yang lebih sering, karena faktor istirahat curian maupun faktor manajemen cukup mengembalikan stamina tukang Kata Kunci: Tukang batu, Waktu Istirahat, Produktivitas
\end{abstract}

\begin{abstract}
Productivity becomes a dominant issue in the construction services industry. High productivity will result in efficient use of resources and cost savings, so that construction companies will achieve adequate profit and have a high competitiveness (competitiveness). Labor productivity can be affected by the energy it consumes and the regular schedule of rest breaks. Rest is needed to restore the physical and mental fitness of the workforce. This research was conducted on 37 masons of building construction work. The work under study is a masonry job. The results showed that age, education, and experience did not significantly affect the productivity. Break time masons, in the form of stolen breaks and management factors, quite a lot ie 1 to 6 minutes per observation (30 minutes). Based on heart rate examination, there is a decrease in productivity in the afternoon. But the mason has not been exhausted yet. So it can be concluded that the amount of break time stolen by the mason in the middle of work greatly affects the stamina of the mason.
\end{abstract}

Keyword : masons, Rest time, Productivity 


\section{PENDAHULUAN}

Di negara yang sedang berkembang seperti Indonesia, sangat dibutuhkan terselenggaranya pembangunan yang dilandasi dengan prinsip efisiensi dan efektivitas. Hal tersebut diperlukan untuk mengatasi keterbatasan sumber daya yang ada, sehingga tercipta produktivitas yang tinggi. Produktivitas menjadi isu dominan dalam industri jasa konstruksi. Dengan produktivitas yang tinggi, akan dicapai efisiensi pemakaian sumber daya serta penghematan biaya, sehingga perusahaan konstruksi akan meraih profit yang memadai serta memiliki daya saing (competitiveness) yang tinggi.

Jam kerja normal yang umumnya diterapkan adalah 8 jam, yaitu mulai pukul 08.00 hingga pukul 16.00, dengan istirahat satu jam pada pukul 12.00 hingga pukul 13.00. Namun demikian, waktu yang sesungguhnya dihabiskan pekerja tidaklah penuh 7 jam

Selain itu produktivitas tenaga kerja pun dapat dipengaruhi oleh energi yang ia konsumsi dan pengaturan jadwal istirahat yang rutin. Istirahat diperlukan untuk memulihkan kesegaran fisik maupun mental tenaga kerja. Hal ini dimana pengaturan waktu kerja yang diselingi dengan beberapa kali waktu istirahat akan menaikkan produktivitas pekerja. Penelitian ini difokuskan pada analisa produktifitas tukang Batu terhadap beban kerja dan waktu istirahat pada pekerjaan konstruksi gedung.

Permasalahan yang akan dibahas dalam penelitian ini yaitu berapa lamakah waktu istirahat yang dipakai pekerja selama masa kerja dalam satu satuan waktu

\section{TINJAUAN PUSTAKA \\ Produktivitas}

produktivitas adalah perbandingan (rasio) antara output per inputnya. Adapun Thomas dan Napolitan (1996)mendefinisikan produktivitas sebagai jam kerja dalam satuan waktu tertentu dibagi dengan banyaknya hasil yang diperoleh dalam satuan waktu yang sama.

Dengan diketahuinya nilai produktivitas, maka akan diketahui pula seberapa efisien sumber-sumber input telah berhasil dihemat (Wignjosoebroto, 2003).

Secara umum, produktivitas selalu didefinisikan sebagai rasio antara keluaran (output) dan masukan (input). Rasio keluaran dan masukan ini dapat juga dipakai pada usaha yang dilakukan manusia. Sebagai ukuran produktivitas kerja manusia, maka rasio tersebut umumnya berbentuk keluaran yang dihasilkan oleh aktivitas kerja dibagi dengan jam kerja yang dikontribusikan sebagai sumber masukan dengan rupiah atau unit produksi lainnya sebagai dimensi tolok ukur (Wignjosoebroto,2003)

\section{Pengaruh Waktu Kerja dan Waktu Istirahat}

Pengaturan waktu kerja - waktu istirahat harus disesuaikan dengan sifat, jenis pekerjan, dan faktor lingkungan. Secara umum, di Indonesia telah ditetapkan lama waktu kerja dalam sehari maksimum adalah 8 jam dan selebihnya adalah istirahat. Memperpanjang waktu kerja lebih dari itu hanya akan menurunkan efisiensi kerja, meningkatkan kelelahan, kecelakaan dan penyakit akibat kerja.

Tetapi dalam pelaksanaannya, banyak perusahaan yang mempekerjakan karyawannya di luar jam kerja (kerja lembur) dengan berbagai alasan. Di sisi lain para tukang juga merasa senang melakukan kerja lembur, karena akan 
mendapatkan penghasilan tambahan di luar penghasilan pokok. Dari sudut pandang fisiologis, kerja lembur sangat merugikan kesehatan. Dalam putaran 24 jam sehari terdapat 3 siklus keseimbangan tubuh yaitu 8 jam kerja, 8 jam interaksi, 8 jam istirahat. Apabila kerja lembur dilakukan di luar 8 jam kerja tersebut sudah tentu siklus keseimbangan akan terganggu. Secara fisiologis, kerja lebih dari 8 jam/hari akan sangat melelahkan. Pada kondisi lelah fungsi panca indera jelas tidak dapat berjalan normal. Dan telah terbukti

pada sesi kerja lembur di samping tingkat produktivitas kerja juga rendah.

Dalam hal lamanya waktu kerja melebihi ketentuan yang telah ditetapkan ( $8 \mathrm{jam} / \mathrm{hari}$ atau $40 \mathrm{jam}$ seminggu), maka perlu diatur waktu - waktu istirahat khusus agar kemampuan kerja dan kesegaran jasmani tetap dapat dipertahankan dalam batas-batas toleransi. Pemberian waktu istirahat tersebut secara umum dimaksudkan untuk :

1. Mencegah terjadinya kelelahan yang berakibat kepada penurunan kemampuan fisik dan mental serta kehilangan efisiensi kerja.

2. Memberi kesempatan tubuh untuk melakukan pemulihan atau penyegaran.

3. Memberi kesempatan waktu untuk melakukan kontak sosial.

Kaitannya dengan masalah waktu istirahat, berdasarkan pengalaman dan pengamatan di lapangan, terdapat empat jenis istirahat yang dilakukan oleh para tukang selama jam kerja berlangsung, yaitu istirahat secara spontan, istirahat curian, istirahat oleh karena ada hubungannya dengan proses kerja dan istirahat yang merupakan ketetapan resmi. Adapun pengertian keempat jenis istirahat tersebut adalah sebagai berikut :

1. Istirahat spontan adalah istirahat pendek segera setelah pembebanan kerja.

2. Istirahat curian adalah istirahat yang terjadi karena faktor kelakuan tukang seperti sengaja mengobrol, merokok sehingga dapat menghambat produksi.

3. Istirahat oleh karena proses kerja tergantung dari bekerjanya mesin-mesin, peralatan atau prosedur-prosedur kerja.

4. Istirahat yang ditetapkan adalah istirahat atas dasar ketentuan perundangundangan yang berlaku, seperti istirahat selama 1 jam setelah melakukan 4 jam kerja, dan diselingi dengan istirahat 15 menit setelah 2 jam kerja dll.

Keempat jenis waktu istirahat tersebut memperlihatkan saling keterkaitannya antara satu dengan yang lainnya. Apabila waktu kerja dan istirahat resmi telah diatur dengan tepat (kapasitas kerja = beban utama + beban tambahan) maka dengan sendirinya istirahat curian dan spontan dapat diminimalisir. Semakin lelah kondisi seorang tukang maka semakin banyak dia melakukan istirahat curian

\section{Penjadwalan Waktu Istirahat untuk Kerja}

Bilamana seseorang harus bekerja berat dengan mengkonsumsikan energi rata-rata sebesar 5,2 Kcal/menit maka secara perlahan-lahan dia akan "menumpuk" kelelahan sampai akhirnya dipaksa untuk berhenti dan memerlukan istirahat untuk beberapa waktu tertentu. Untuk mengestimasikan jumlah waktu untuk istirahat - baik yang harus yang harus dijadwalkan atau tidak dijadwalkan yang diperlukan dalam pelaksanaan kerja dapat diformulasikan sebagai berikut (Wignjosoebroto, 2003) :

Pengukuran jadwal waktu istirahat dilakukan dengan dasar pertimbangan pemakaian energi yang dikonsumsi untuk bekerja. Untuk kegiatan kegiatan yang dikualisifikasikan ringan atau moderat akan memerlukan waktu istirahat sekitar 
10 - 15 menit yang dijadwalkan pagi atau siang hari diluar jadwal istirahat makan siang.

Istirahat diperlukan untuk memulihkan kesegaran fisik ataupun mental tenaga kerja. Jumlah total waktu yang diperlukan untuk istirahat rata - rata $15 \%$ dari total waktu kerja, untuk kerja fisik biasa. Untuk pekerjaan normal fisik berat (kerja berat/kasar), prosentase waktu istirahat yang diperlukan bisa mencapai $30 \%$.

Beberapa penelitian membuktikan bahwa pengaturan jadwal kerja yang diselingi dengan beberapa kali waktu istirahat akan menaikkan efisiensi pekerja. Sebagai contoh, pengurangan waktu kerja dari 8,75 jam/hari menjadi 8 jam/hari akan menghasilkan peningkatan prestasi $3 \%$ hingga $10 \%$.

\section{METODE PENELITIAN}

Penelitian ini dilaksanakan dengan cara mengamati fenomena yang ada di lapangan. Obyek penelitian adalah tukang batu. Oleh karena obyek penelitian adalah manusia maka untuk memperoleh data yang valid dan reliabel, harus ada kerja sama yang baik antara peneliti, obyek penelitian dan pihak-pihak yang terkait dalam penelitian, sehingga langkah-langkah yang direncanakan dalam penelitian ini dapat terlaksana dengan baik.

Dalam pengumpulan data pada penelitian ini dilakukan dengan metode pengamatan (observasi) secara langsung di lapangan yaitu Waktu istirahat pekerja Setiap tukang diamati selama tiga hari kerja, dengan tiga kali pengamatan setiap hari selama 30 menit. Dengan demikian setiap tukang diamati selama 9 kali. setelah tukang menyelesaikan pekerjaan pasangan bata selama satu satuan waktu yang ditentukan

\section{HASIL DAN PEMBAHASAN}

\section{Profil Tukang BatuBerdasarkan Pendidikan Terakhir}

Rekapitulasi profil tukang batu yang berpartisipasi dalam penelitian berdasarkan tingkat pendidikan terakhir. Tukang batu dengan pendidikan terakhir SD berjumlah 8 orang atau sekitar 21,621 persen, kemudian tingkat pendidikan terakhir SMP berjumlah 22 orang atau sekitar 59,459 persen, dan untuk tingkat pendidikan terakhir SMA berjumlah 7 atau sekitar 18,918 persen. Secara keseluruhan, tingkat pendidikan terakhir SMP mendominasi jumlah tukang bata, kemudian diikuti oleh SD, dan kemudian SMA.

\section{Profil Tukang Batu berdasarkan Usia}

Kelompok usia kurang dari 20 tahun berjumlah 0 atau sekitar $0 \%$, untuk kelompok usia 20 sampai 25 tahun berjumlah 6 tukang bata atau sekitar 16,21\%, kemudian kelompok usia 26 sampai 30 tahun berjumlah 19 tukang bata atau sekitar 51,35\%. Selanjutnya, kelompok usia 31 sampai 35 tahun berjumlah 7 tukang bata atau sekitar 18,91\%, dan kelompok usia di atas 35 tahun berjumlah 5 tukang bata atau sekitar 13,51. Secara keseluruhan, kelompok usia 25 sampai dengan 30 tahun mendomenitasi jumlah tukang bata yang berpartisipasi dalam penelitian ini, kemudian diikuti oleh kelompok usia 20 sampai dengan 25 tahun. Tukang bata yang berpartisipasi dalam penelitian ini terhitung masih muda karena hampir 51,35 persen berusia 25 sampai dengan 30 tahun

\section{Profil Tukang Batu berdasarkan pengalaman kerja}


Berdasarkan hasil pengamatan rekapitulasi profil tukang batu berdasarkan pengalaman kerja tukang batu tersebut. Untuk pengalaman kerja kurang dari 5 tahun berjumlah 11 tukang bata atau sekitar 29,72\%. Pengalaman kerja 5 sampai dengan 10 tahun berjumlah 17 tukang bata atau sekitar 45,94\%, dan pengalaman kerja 11 sampai dengan 15 tahun berjumlah 9 tukang bata atau sekitar 24,32

Dilihat dari data yang ada maka dapat terlihat bahwa tukang - tukang yang berpartisipasi dalam penelitian ini adalah memiliki pengalaman kerja antara 5 sampai 10 tahun, kemudian diikuti pengalaman kerja kurang dari 5 tahun, berikutnya 11 sampai dengan 15 tahun.

\section{Analisa dan pengaruh frekuensi dan waktu istirahat pada tukang batu}

Untuk menghitung analisa pengaruh frekuensi dan waktu istirahat pada tukang penelitian ini digunakan sampel produktivitas dan tingkat kelelahan tukang bata sebanyak 37 tukang pada proyek konstruksi yaitu pekerjaan pesantren Setelah data lapangan terkumpul, langkah selanjutnya adalah melakukan pemprosesan data. Langkah selanjutnya adalah melakukan analisa terhadap produktivitas dan pulse rata-rata agar dapat dikelompokkan ke dalam kategori beban kerja

Dapat dilihat pada hari pertama tukang 1 memiliki pulse rata-rata 75,6 denyut/menit dengan produktivitas rata-rata $0,57 \mathrm{~m} / 30$ menit, jadi tukang ini termasuk dalam klasifikasi beban kerja yang ringan, sehingga dapat disimpulkan bahwa tukang 1 belum mengalami kelelahan dan masih bisa mengoptimalkan waktu kerja yang diberikan. Setelah diketahui pulse dan produktivitas rata-rata tukang, langkah selanjutnya adalah membuat tabel keseluruhan tukang dengan membandingkan data antara profil tukang, pulse serta produktivitasnya.

Langkah selanjutnya adalah pengelompokan denyut jantung / pulse berdasarkan variasi waktu pengambilan data yaitu pada pagi hari, siang, dan sore hari.

Dari hasil perhitungan dan pengamatan menunjukkan nilai pulse 72.33 , nilai ini diperoleh dari rata-rata keseluruhan nilai pulse yang diambil pada pagi hari. Begitu juga pada kolom ke dua dimana menunjukkan angka 72,94. Data ini diperoleh dari rata-rata keseluruhan nilai pulse pada pengamatan siang hari. Pada sore hari nilai pulse menunjukkan angka 72,32, nilai ini juga diperoleh dari ratarata keseluruhan nilai pulse pada pengamatan sore hari. Produktivitas rata-rata diperoleh dari jumlah keseluruhan volume yang dihasilkan pada pagi, siang dan sore hari. Kemudian dibagi jumlah tukang keseluruhan sehingga didapatkan produktivitas rata-rata per tukangnya untukpekerjaanselama30menit

\section{Frekuensi dan Waktu Istirahat}

Pada pengamatan tukang bata 1, volume produktivitas yang dihasilkan oleh tukang cukup bervariasi antara hari pertama, ke dua dan ke tiga, namun selisih produktivitas tersebut tidak berbeda jauh. produktivitas rata-rata yang dihasilkan pada hari pertama adalah 0,62 $\mathrm{m} 2 / 30$ menit, sedangkan pada hari ke dua produktivitas yang dihasilkan adalah $0,57 \mathrm{~m} 2 / 30$ menit dan pada hari ke tiga adalah 0,66 m2/30 menit. Data ini menunjukan bahwa produktivitas yang dihasilkan setiap harinya tidak berbeda jauh.

Pada pengamatan ini, juga dapat dilihat angka pulse yang dihasilkan selama tiga hari dengan variasi pengambilan data pagi, siang, dan sore hari. Variasi pengambilan data ini dimaksudkan agar dapat diketahui tingkat kelelahan tukang, 
dimana pada saat pagi hari kondisi tukang masih "segar", sedangkan siang hari tukang mulai menunjukan tanda-tanda kelelahan hingga pada saat sore hari tukang mengalami kelelahan yang akan membuat produktivitas tukang menurun. Namun dari hasil penelitian, angka pulse yang dihasilkan tukang sangatlah berbeda dari konsep yang sebenarnya, dapat dilihat dari yang menunjukan bahwa jumlah pulse rata-rata yang dihasilkan pada hari pertama adalah 75,6 detik/menit sedangkan hari ke dua adalah $77 \mathrm{detik} / \mathrm{menit}$ dan hari ke tiga adalah 83 detik/menit. Data ini mengindikasikan bahwa tukang 1 belum mengalami kelelahan yang berarti, karena tingkat beban kerja tukang di sini masih tergolong ringan.

Jumlah pulse dan produktivitas yang dihasilkan tukang selama tiga hari menunjukan bahwa waktu istirahat curian yang dilakukan tukang cukup banyak. Hal ini tentu saja berdampak terhadap produktivitas yang dihasilkan tukang, yang belum optimal dan masih bisa ditingkatkan. dapat dilihat bahwa banyaknya waktu istirahat yang diperoleh tukang seperti mengobrol, merokok, ataupun menunggu material cukup banyak dan ini dapat membuat stamina tukang kembali pulih dengan cepat.

\section{Regresi}

Berikut ini adalah pembahasan hubungan antara pulse dan produktivitas tukang di tinjau dari analisa regresi. bahwa nilai pulse berpengaruh terhadap jumlah produksi yang dilakukan tukang. Namun tidak semua tukang memperlihatkan bahwa tingkat pulse sangat berpengaruh terhadap produktivitas, pada penelitian ini beberapa tukang menunjukkan tingkat kelelahan yang lebih tinggi tidak berpengaruh terhadap produksi yang dilakukan. Di pagi hari persamaan regresi yang dihasilkan tukang adalah $y=15,07 x+63,8$. Persamaan $y$ ini dapat digunakan untuk meramalkan apabila nilai $\mathrm{x}$ diketahui. Jika produksi yang dilakukan sebesar $0,7 \mathrm{~m} 2 / 30$ menit, maka ramalan nilai pulse yang dihasilkan adalah $\mathrm{y}=15,07(0,70)+63,8=74,38$ denyut $/$ menit. Di siang hari persamaan regresi yang dihasilkan adalah $\mathrm{y}=13,57 \mathrm{x}+65,11$ dan sore hari adalah $y=5,752 x+70,11$. Dari persamaan ini, dapat diramalkan bahwa tinggi atau rendah nya tingkat kelelahan tukang tergantung dari nilai produksi yang dilakukan tukang.

\section{KESIMPULAN}

Berdasarkan penelitian yang dilakukan terhadap 37 tukang pasangan bata, maka dapat diambil kesimpulan penelitian sebagai berikut :

1. Pada penelitian ini faktor umur, pendidikan, maupun pengalaman tidak terlalu berpengaruh pada produktivitas yang dihasilkan. Variasi profil tukang di beberapa proyek penelitian tidak membuktikan bahwa tingkat produksi yang di hasilkan berbeda-beda.

2. Waktu istirahat yang diperoleh tukang pada penelitian ini dalam sehari sangat bervariatif. Pada penelitian ini waktu istirahat curian maupun faktor manajemen yang diperoleh tukang antara 1 menit hingga 6 menit setiap pengamatan (30 menit). Maka dapat disimpulkan bahwa waktu istirahat yang diperoleh dalam sehari cukup banyak.

3. Berdasarkan penelitian di lapangan, maka dapat diketahui bahwa nilai pulse yang di hasilkan keseluruhan tukang berbeda beda. Variasi waktu kerja antara pagi, siang dan sore hari cukup mempengaruhi tingkat kelelahan tukang dan produktivitas tukang. 
a. Pada pagi hari rata rata tukang menghasilkan nilai pulse sebesar 72,33 denyut/menit dan produktivitas rata-rata yang dilakukan tukangdi pagi hari selama 30 menit adalah $0,56 \mathrm{~m}^{2}$. Maka dapat disimpulkan bahwa tukang di pagi hari belum mengalami kelelahan. Tingkat pulse yang dihasilkan tukang mengindikasikan bahwa kategori beban kerja yang dialami tukang pada pagi hari masih tergolong ringan dan tingkat produksi masih dapat dioptimalkan.

b. Pada siang hari rata-rata tukang pasangan bata menghasilkan nilai pulse sebesar 72,94 denyut/menit dan produktivitas rata-rata yangdilakukan tukang di siang hari selama 30 menit adalah $0,581 \mathrm{~m}^{2}$. Hal ini menunjukkan bahwa tukang pada siang hari juga belum mengalami kelelahan karena tingkat beban kerja yang dihasilkan juga masih tergolong ringan.

c. Sore hari rata-rata tukang pasangan bata menghasilkan nilai pulse sebesar 72,32 denyut/menit dan produktivitas rata-rata yang dilakukan tukang di sore hari selama 30 menit adalah $0,558 \mathrm{~m}^{2}$. Pada sore hari terlihat bahwa terjadi penurunan tingkat produksi rata-rata, namun pada penelitian ini tukang belum mengalami kelelahan. Dapat disimpulkan bahwa banyaknya waktu istirahat curian yang diperoleh tukang di tengah bekerja sangat mempengaruhi stamina tukang.

4. Waktu istirahat yang di peroleh di tengah bekerja tukang sangat mempengaruhi tingkat produktivitas tukang. Terlihat pada penelitian ini bahwa waktu isitrahat curian cukup banyak diperoleh tukang. Beberapa faktor ini tentu dapat berdampak terhadap tingkat kelelahan tukang. Secara keseluruhan tukang pada penelitian ini dapat disimpulkan belum mengalami kelelahan dan belum membutuhkan pengaturan jadwal istirahat yang lebih sering, karena faktor istirahat curian maupun faktor manajemen cukup mengembalikan stamina tukang.

\section{DAFTAR PUSTAKA}

Djojowirono, Soegeng. 2005. Manajemen Konstruksi, Biro Penerbit TS. UGM: Yogyakarta.

Dipohusodo, Istimawan. 1996. Manajemen proyek \& konstruksi (vol.1). Yogyakarta: Kanisius.

Dipohusodo, Istimawan. 1996. Manajemen proyek \& konstruksi (vol.2). Yogyakarta: Kanisius.

Husen, Akbar. 2011. Manajemen Proyek. ANDI Offset. Yogyakarta

Soeharto, Imam. 1995. Manajemen proyek. Erlangga. Jakarta.

Sugiyono. 2011. Statistika Untuk Penelitian. Alfabeta. Bandung

Soeharto, Imam. 1997. Manajemen Proyek Dari Konseptual Sampai Operasional. Erlangga. Jakarta.

Tim Manajemen Konstruksi. Vil Press. 2001

Wignjosoebroto, Sritomo. 2003. Ergonomi studi gerak dan waktu. Edisi Pertama. Guna Widya. Jakarta

Wulfram I. Ervianto. 2005. Manajemen Proyek Konstruksi. ANDI Offset. Yogyakarta. 